\title{
Perbedaan Tingkat Perilaku Agresi Berdasarkan Jenis Kelamin pada Siswa Sekolah Menengah Kejuruan Kota Yogyakarta
}

\author{
Wahyu Nanda Eka Saputra, Nadiah Hanifah, Dika Nur Widagdo \\ Program Studi Bimbingan dan Konseling, Fakultas Keguruan dan Ilmu Pendidikan, \\ Universitas Ahmad Dahlan, Jl. Pramuka No. 42, Yogyakarta, Daerah Istimewa Yogyakarta, Indonesia 55161 \\ E-mail: wahyu.saputra@bk.uad.ac.id
}

Artikel diterima: 7 Oktober 2017; direvisi 20 Desember 2017; disetujui 27 Desember 2017

\begin{abstract}
The purpose of this study is to identify whether there are differences between male student aggression behavior and female students aggresive behavior in Yogyakarta. This comparative study involved 160 students from Sekolah Menengah Kejuruan Muhammadiyah in Yogyakarta as a sample. Simple Random Sampling technique were used to choose sample. The instrument used is the scale of aggression behavior. Independent Samples Test were used to analysis the data. The research findings show that there is no significant difference between male student aggression behavior and female students aggresive behavior. This study recommends counseling service to reduce and overcome student aggression behavior.
\end{abstract}

Keywords: aggressive behavior; gender differences; vocational high school

\begin{abstract}
Abstrak: Tujuan penelitian ini adalah untuk mengidentifikasi apakah terdapat perbedaan perilaku agresi siswa laki-laki dan perempuan di Kota Yogyakarta. Penelitian komparatif ini melibatkan 160 orang siswa yang tersebar di Sekolah Menengah Kejuruan (SMK) Muhammadiyah di Kota Yogyakarta sebagai sampel. Pemilihan sampel menggunakan teknik Simple Random Sampling. Instrumen yang digunakan adalah skala perilaku agresi. Analisis data untuk mengidentifikasi perbedaan perilaku agresi siswa laki-laki dan perempuan menggunakan Independent Samples Test. Temuan penelitian menunjukkan bahwa tidak terdapat perbedaan yang signifikan antara perilaku agresi siswa laki-laki dan siswa perempuan. Penelitian ini merekomendasikan perlu pelayanan konseling untuk mengurangi dan mengatasi perilaku agresi siswa.
\end{abstract}

Kata kunci: perilaku agresi; perbedaan jenis kelamin; sekolah menengah kejuruan

Klitih merupakan salah satu topik yang akhir-akhir ini sedang hangat di Yogyakarta. Perilaku klitih merupakan bentuk dari agresi yang menyakiti fisik seseorang. Di Yogyakarta klitih telah menjadi masalah klasik yang terus terjadi sampai sekarang. Kasus terbaru, menyebutkan seorang pelajar Sekolah Menengah Pertama (SMP) meninggal dunia setelah ditusuk oleh sekelompok orang di Jalan Kenari Sleman sekitar pukul 12.45 WIB (Kusuma, 2017). Hal ini tentu menjadi keprihatinan, khususnya bagi dunia pendidikan.

Perilaku klitih adalah salah satu bentuk dari perilaku agresi. Perilaku agresi adalah perilaku yang secara sengaja bermaksud untuk melukai secara fisik, verbal serta menghancurkan harta benda orang lain (Atkinson, Atkinson, Smith, \& Hilgard, 1987). Agresi fisik contohnya adalah memukul, menendang, atau melukai secara fisik. Agresi verbal contohnya adalah mengumpat, mengejek, dan meremehkan. Agresi yang merusak harta benda orang lain contohnya adalah merusak jam, sepeda atau benda milik orang lain. 
Beberapa penelitian terdahulu menunjukkan bahwa perilaku agresi masih menjadi masalah siswa. Salah satu contoh hasil penelitian mengenai tingkat perilaku agresi adalah sebagai berikut: sangat tinggi 13 orang (8,67\%); tinggi 33 orang (22,\%); sedang 51 orang (34\%); rendah 48 orang (32\%); dan sangat rendah 5 orang (3,33\%) (Guswani \& Kawuryan, 2011). Tingkat perilaku agresi remaja laki-laki adalah sebagai berikut: sangat tinggi sebesar $15 \%$; tinggi sebesar $23 \%$; sedang sebesar 38\%; rendah sebesar $21 \%$; dan sangat rendah sebesar $2.6 \%$, sedangkan remaja perempuan kategori tingkat perilaku agresinya adalah sebagai berikut: sangat tinggi sebesar 5.1\%; tinggi sebesar $18 \%$; sedang sebesar $31 \%$; rendah sebesar $36 \%$; dan sangat rendah sebesar $10 \%$ (Aulya, Ilyas, \& Ifdil, 2016).

Beberapa penelitian menyebutkan bahwa perilaku agresi disebabkan oleh faktor tertentu, salah satunya adalah perceraian orang tua. Remaja yang berasal dari keluarga bercerai ternyata lebih agresif bila dibandingkan dengan remaja yang berasal dari keluarga utuh (Nisfiannoor \& Yulianti, 2005). Siswa yang orang tuanya bercerai memiliki kebahagiaan yang kurang. Hal ini akan mendorong siswa untuk mencari hal lain yang dapat membuat dirinya bahagia, termasuk dengan cara melukai orang lain secara sengaja. Seorang anak akan memiliki tingkat subjective well-being yang cenderung rendah ketika dalam keadaan orang tuanya bercerai (Dewi \& Utami, 2008). Hal tersebut ditandai dengan adanya efek negatif seperti merasa sedih, malu, kecewa, sebal, dan bahkan benci karena adanya pertengkaran orang tuanya.

Perilaku agresi memiliki dampak negatif, utamanya adalah turunnya hasil belajar siswa. Siswa korban bullying akan memiliki ketakutan ketika tampil di sekolah dan berdampak pada turunnya prestasi belajar siswa (Dewi \& Utami, 2008). Iklim sekolah yang kurang kondusif juga memiliki pengaruh yang signifikan terhadap menurunnya prestasi siswa di sekolah (MacNeil, Prater, \& Busch, 2009).

Perilaku agresi dapat berpotensi dilakukan oleh siswa laki-laki dan perempuan. Penelitian ini berupaya untuk mengidentifikasi perbedaan tingkat perilaku agresi pada siswa laki-laki dan perempuan SMK Muhammadiyah di Kota Yogyakarta. Hal ini perlu diidentifikasi karena penelitian ini akan menjadi dasar bagi konselor dalam merancang program dan memberikan layanan konseling bagi siswa. Pemberian layanan konseling untuk mereduksi perilaku agresi siswa, dapat diprogram sesuai dengan karateristik masing-masing siswa.

\section{METODE}

Penelitian ini dirancang sebagai penelitian komparatif, dengan sampel 160 orang siswa SMK Muhammadiyah di Kota Yogyakarta. Teknik pengambilan sampel pada penelitian ini adalah random sampling. Instrumen yang digunakan adalah skala perilaku agresi. Analisis data untuk mengidentifikasi perbedaan perilaku agresi siswa laki-laki dan Perempuan menggunakan rumus Independent Samples Test dengan bantuan program SPSS for Windows Release 20.

\section{HASIL}

Hasil pengolahan data Independent Samples Test dengan menggunakan bantuan software SPSS Versi 20. Analisis ini dipilih untuk melihat ada atau tidaknya perbedaan perilaku agresif siswa ditinjau dari jenis kelamin. hasil uji beda perilaku agresi ditinjau dari jenis kelamin disajikan pada tabel 1. Pada tabel 1 tampak bahwa f yang diperoleh ialah 0.135 dengan signifikansi 0.714 yang berarti lebih besar dari $0.05(0.714>0.05)$ maka hal ini berarti varian kelompok populasi adalah homogen. Dengan demikian persyaratan homogenitas untuk analisis komparasi terpenuhi. Selanjutnya, dari hasil analisis data diperoleh koefisien t hitung sebesar 0.970 dengan probabilitas 0.333 apabila dibandingkan dengan 0.05 maka nilai probabilitasnya lebih besar yang berarti tidak terdapat perbedaan perilaku agresi siswa ditinjau dari jenis kelamin. Dengan demikian hasil menujukkan bahwa tidak ada perbedaan perilaku agresi yang signifikan antara siswa laki-laki dan siswa perempuan di SMK Yogyakarta 
Tabel 1 Output Analisis Independent Samples Test menggunakan SPSS

\begin{tabular}{|c|c|c|c|c|c|c|c|c|c|c|}
\hline \multicolumn{11}{|c|}{ Independent Samples Test } \\
\hline & & \multicolumn{2}{|c|}{$\begin{array}{c}\text { Levene's Test } \\
\text { for Equality of } \\
\text { Variances }\end{array}$} & \multicolumn{7}{|c|}{ t-test for Equality of Means } \\
\hline & & \multirow[t]{2}{*}{$\mathrm{F}$} & \multirow[t]{2}{*}{ Sig. } & \multirow[t]{2}{*}{$\mathrm{t}$} & \multirow[t]{2}{*}{$\mathrm{df}$} & \multirow[t]{2}{*}{$\underset{\text { (2-tailed) }}{\text { Sig. }}$} & \multirow[t]{2}{*}{$\begin{array}{c}\text { Mean } \\
\text { Differ- } \\
\text { ence }\end{array}$} & \multirow[t]{2}{*}{$\begin{array}{l}\text { Std. } \\
\text { Error } \\
\text { Differ- } \\
\text { ence }\end{array}$} & \multicolumn{2}{|c|}{$\begin{array}{c}95 \% \text { Confi- } \\
\text { dence Inter-val } \\
\text { of the Differ- } \\
\text { ence }\end{array}$} \\
\hline & & & & & & & & & Lower & Upper \\
\hline \multirow[t]{2}{*}{$\begin{array}{l}\text { Skor } \\
\text { Agresi }\end{array}$} & $\begin{array}{l}\text { Equal } \\
\text { variances } \\
\text { assumed }\end{array}$ & .135 & .714 & .970 & 158 & .333 & 2.422 & 2.496 & -2.508 & 7.353 \\
\hline & $\begin{array}{l}\text { Equal } \\
\text { variances } \\
\text { not } \\
\text { assumed }\end{array}$ & & & .902 & 53.608 & .371 & 2.422 & 2.684 & -2.961 & 7.805 \\
\hline
\end{tabular}

\section{PEMBAHASAN}

\section{Tingkat Agresi Berdasarkan Jenis Kelamin}

Temuan dalam penelitian ini menunjukkan bahwa tidak terdapat perbedaan perilaku agresi yang signifikan antara laki-laki dan perempuan. Ini menunjukkan bahwa tingkat perilaku agresi siswa laki-laki dan perempuan di SMK Muhammadiyah di Kota Yogyakarta cenderung sama pada. Siswa laki-laki cenderung melakukan agresi dalam bentuk agresi fisik dan verbal, sedangkan siswa perempuan cenderung melakukan perilaku agresi dalam bentuk kemarahan dan kebencian. Tentunya ini menjadi permasalahan yang kompleks yang perlu menjadi perhatian banyak pihak, terutama di dunia pendidikan.

Hasil penelitian ini diukur dengan menggunakan skala perilaku agresi (W. N. E. Saputra \& Handaka, 2017a). Skala perilaku agresi yang dikembangkan tersebut terdiri dari 38 butir yang valid dengan koefisien reliabilitas 0,826 yang termasuk dalam kategori reliabilitas tinggi. Berdasarkan hasil analisis, dapat dinyatakan bahwa skala perilaku agresi layak digunakan untuk mengukur tingkat perilaku agresi siswa.

Skala perilaku agresi yang digunakan untuk melakukan identifikasi tingkat perilaku agresi berdasarkan jenis kelamin siswa dikembangkan menggunakan konsep bahwa perilaku agresif sebagai perilaku atau kecenderungan perilaku yang niatnya untuk menyakiti orang lain baik secara fisik maupun secara psikologis (Buss \& Perry, 1992). Agresivitas dapat dikalasifikasi menjadi empat aspek (Buss \& Perry, 1992). Pertama, agresi fisik yaitu agresi yang dilakukan untuk melukai orang lain secara fisik. Contoh agresi fisik adalah: memukul; menendang; dan melukai. Kedua, agresi verbal yaitu tindakan agresi yang bertujuan untuk menyakiti; mengganggu; atau membahayakan orang lain dalam bentuk penolakan dan ancaman melalui respon vokal dalam bentuk verbal. Contoh agresi verbal antara lain: membentak; mengumpat; dan mengejek. Ketiga, kemarahan merupakan emosi negatif yang disebabkan oleh harapan yang tidak terpenuhi dan bentuk ekspresinya dapat menyakiti orang lain serta dirinya sendiri. Beberapa bentuk kemarahan adalah perasaan marah; kesal; dan sebal. Termasuk di dalamnya adalah irritability, yaitu mengenai temperamental, kecenderungan untuk cepat marah, dan kesulitan mengendalikan amarah. Keempat, hostility merupakan tindakan yang mengekspresikan kebencian, permusuhan, antagonisme, ataupun kemarahan kepada pihak lain. Hostility adalah suatu bentuk agresi yang tergolong agresi covert (tidak terlihat).

Beberapa penelitian telah dilakukan untuk mengidentifikasi perbedaan tingkat perilaku agresi siswa laki-laki dan perempuan. Berbeda dengan temuan penelitian ini, hasil penelitian sebelumnya menunjukkan bahwa tingkat perilaku agresi siswa laki-laki berbeda signifikan dengan siswa 
perempuan (Aulya, Ilyas \& Ifdil, 2016). Perilaku agresi siswa laki-laki pada umumnya berada pada ketegori sedang (38\%) dan perilaku agresi siswa perempuan pada umumnya berada pada kategori rendah (36\%). Perbedaan hasil penelitian ini menjadi menarik untuk dianalisis. Salah satu faktor yang menjadi penyebab budaya. Penelitian ini dilakukan di Yogyakarta, sedangkan penelitian Aulya, Ilyas \& Ifdil (2016) dilakukan di Sumatra Barat yang secara budaya tentunya berbeda.

Sama halnya dengan penelitian lain yang menunjukkan bahwa laki-laki kemungkinan besar akan terlibat dalam agresi relasional teman sebaya baik proaktif maupun reaktif sedangkan perempuan cenderung melakukan agresi relasional romantis (Murray-Close, Ostrov, Nelson, Crick, \& Coccaro, 2010). Penelitian tersebut memiliki kesamaan dengan temuan penelitian ini yang menyatakan bahwa baik siswa laki-laki dan perempuan memiliki kecenderungan yang relatif sama dalam melakukan perilaku agresi. Bedanya, jika remaja laki-laki perilaku agresi lebih cenderung proaktif dan reaktif terhadap situasi tertentu dengan teman sebaya, sedangkan remaja perempuan lebih kepada perilaku agresi yang kaitannya dengan relational romantis.

Pergeseran dan perkembangan teknologi menjadi faktor yang turut menyumbang persamaan perbedaan perilaku agresi antara laki-laki dan perempuan. Konten dan teknologi dalam video game yang mengarah pada perilaku agresi dapat dinikmati dan dimainkan oleh semua kalangan, baik siswa laki-laki dan perempuan dan ini dapat berpengaruh pada munculnya perilaku agresi sesuai dengan konten video game yang digunakan (Barlett, Rodeheffer, Baldassaro, Hinkin, \& Harris, 2008; Ivory \& Kalyanaraman, 2007). Dengan adanya teknologi baru, saat ini juga terjadi peningkatan risiko remaja menjadi korban agresi yang dilakukan oleh rekan sejawat (David-Ferdon \& Hertz, 2007). Beberapa penelitian di atas telah menunjukkan bahwa pergeseran teknologi telah menjadi suatu isu baru yang berdampak pada siswa, baik siswa laki-laki dan perempuan karena mereka memiliki peluang yang sama untuk mengaksesnya.

Peran guru dan warga sekolah yang lain juga menjadi salah satu faktor yang berperan besar yang menyebabkan tidak adanya perbedaan perilaku agresi antara laki-laki dan perempuan. Meskipun sebagian besar guru memahami dampak signifikan dari cyberbullying terhadap anak-anak dan khawatir tentang cyberbullying, kebanyakan dari mereka tidak menganggapnya sebagai masalah di sekolah (Li, 2008). Hal ini tentunya memberikan peluang bagi siswa baik laki-laki maupun perempuan untuk meluapkan emosi mereka dalam bentuk agresi jika mereka sedang mengalami situasi yang berpotensi pada munculnya konflik.

Ability Emotional Intelligence juga turut menyumbang muncul dan meningkatnya perilaku agresi siswa (García-Sancho, Salguero, \& Fernández-Berrocal, 2017). Menurut penelitian lain, emotional self-efficacy juga turut menyumbang pada munculnya perilaku agresi siswa (Valois, Zullig, \& Revels, 2017). Berdasarkan penelitian tersebut dapat dipahami bahwa siswa yang memiliki kemampuan mengelola emosi yang baik akan memiliki kecenderungan untuk mampu meminimalisir munculnya perilaku agresi. Sebaliknya, siswa yang memiliki kemampuan mengelola emosi yang rendah akan cenderung kesulitan meregulasi emosi untuk meminimalisir munculnya perilaku agresi, sehingga regulasi emosi menjadi salah satu unsur penting bagi siswa untuk memunculkan atau meminimalisir perilaku agresi. Hal ini dikarenakan regulasi emosi memiliki pengaruh yang lebih besar terhadap perilaku agresi (Garofalo, Holden, Zeigler-Hill, \& Velotti, 2016; Roberton, Daffern, \& Bucks, 2012; Scott, Stepp, \& Pilkonis, 2014).

\section{Konseling Kedamaian untuk Mereduksi Perilaku Agresi}

Penelitian ini merekomendasikan untuk menyelenggarakan layanan konseling untuk mengurangi dan mengatasi perilaku agresi siswa. Salah satunya adalah dengan konseling kedamaian (W. N. E. Saputra \& Handaka, 2017b). Konseling kedamaian mendorong siswa untuk berlatih berpikir damai sehingga mampu mengurungkan niat berperilaku agresi. Konseling kedamaian itu sendiri merupakan pengembangan dari konsep pendidikan kedamaian. Ada peluang bagi pendidik terutama konselor untuk menerapkan pendidikan kedamaian di latar pendidikan dalam format konseling (Saputra, 2016). Lebih jauh, gagasan Saputra, Widiasari, \& Dina, (2016) menunjukkan pendidikan kedamaian 
yang ditilik dari perspektif islam berpotensi untuk diimplementasikan dalam sesi konseling. Selain konseling kedamaian, bimbingan kelompok dengan teknik sosiodrama juga telah terbukti mampu mengurangi agresif verbal siswa (Winarlin, Lasan, \& Widada, 2016).

Konseling kedamaian itu sendiri merupakan pengembangan dari konsep pendidikan kedamaian (peace education) yang diintegrasikan dan diterapkan dalam sesi konseling (Saputra \& Handaka, 2017b). Pendidikan kedamaian adalah suatu filosofi dan proses yang berkaitan dengan akuisisi pengetahuan dan keterampilan menciptakan perdamaian, yang mana tujuan utama dari pendidikan kedamaian adalah untuk mengekspos peserta didik dengan tidak menggunakan kekerasan dalam menangani konflik atau situasi tertentu yang berpotensi pada munculnya konflik (Adeyemi \& Salawudeen, 2014), hal ini sesuai dengan pandangan dasar dari Mahatma Gandhi tentang konsep "non-violence" (Biswas, 2015).

Dalam konseling kedamaian, konselor membuat program-program untuk melatih konseli agar memiliki dan mengembangkan pikiran damai, karena sejatinya kedamaian berada pada pikiran manusia (Anand, 2014). Pikiran damai itulah yang akan meminimalisir keinginan siswa untuk berperilaku agresi ketika mereka sedang mengalami situasi tertentu. Sampai di sini, dapat kita pahami bahwa konseling kedamaian adalah konseling yang berakar dari filosofis pendidikan kedamaian yang secara perlahan berusaha untuk mengikis konflik-konflik yang telah terjadi dan menimbulkan suatu ketenangan hati baik yang bersifat intrapersonal dan interpersonal.

\section{SIMPULAN}

Temuan dalam penelitian menunjukkan bahwa tidak ada perbedaan yang signifikan antara perilaku agresi siswa laki-laki dan siswa perempuan. Temuan penelitian ini tentunya menjadi temuan yang berharga karena telah memberikan gambaran bahwa perilaku agresi adalah masalah yang perlu diperhatikan karena pelakunya tidak hanya siswa laki-laki, tetapi juga siswa perempuan. Penelitian ini merekomendasikan perlu pelayanan konseling untuk mengurangi dan mengatasi perilaku agresi siswa, salah satunya lewat konseling kedamaian.

\section{DAFTAR RUJUKAN}

Adeyemi, B. A., \& Salawudeen, M. O. (2014). The Place of Indigenous Proverbs in Peace Education in Nigeria: Implications for Social Studies Curriculum. International Journal of Humanities and Social Science, 4(2), 186-192.

Anand, S. (2014). The Contemporary Issues and Significance of Peace Education in India. International Journal of Research in Humanities, Arts and Literature, 2(10), 47-54.

Atkinson, R. C., Atkinson, R. L., Smith, E. E., \& Hilgard, E. R. (1987). Introduction to Psychology. San Diego: Harcourt Brace.

Aulya, A., Ilyas, A., \& Ifdil, I. (2016). Perbedaan Perilaku Agresif Siswa Laki-laki dan Siswa Perempuan. Jurnal EDUCATIO: Jurnal Pendidikan Indonesia, 2(1), 91-97.

Barlett, C., Rodeheffer, C. D., Baldassaro, R., Hinkin, M. P., \& Harris, R. J. (2008). The Effect of Advances in Video Game Technology and Content on Aggressive Cognitions, Hostility, and Heart Rate. Media Psychology, 11(4), 540-565.

Biswas, P. (2015). Mahatma Gandhi's Views on Peace Education. Education Journal. Special Issue: Gender, Peace and Educ, 4(1), 10-12.

Buss, A. H., \& Perry, M. (1992). The Aggression Questionnaire. Journal of Personality and Social Psychology, 63(3), 452.

David-Ferdon, C., \& Hertz, M. F. (2007). Electronic Media, Violence, and Adolescents: An Emerging Public Health Problem. Journal of Adolescent Health, 41(6), S1-S5.

Dewi, P. S., \& Utami, M. S. (2008). Subjective Well-being Anak dari Orang Tua yang Bercerai. Jurnal Psikologi, 35(2), 194-212. 
García-Sancho, E., Salguero, J. M., \& Fernández-Berrocal, P. (2017). Ability Emotional Intelligence and its Relation to Aggression Across Time and Age Groups. Scandinavian Journal of Psychology, 58(1), 43-51.

Garofalo, C., Holden, C. J., Zeigler-Hill, V., \& Velotti, P. (2016). Understanding the Connection between Self-esteem and Aggression: The Mediating Role of Emotion Dysregulation. Aggressive Behavior, 42(1), 3-15.

Guswani, A. M., \& Kawuryan, F. (2011). Perilaku Agresi pada Mahasiswa Ditinjau dari Kematangan Emosi. Jurnal Psikologi: PITUTUR, 1(2), 86-92.

Ivory, J. D., \& Kalyanaraman, S. (2007). The Effects of Technological Advancement and Violent Content in Video Games on Players' Feelings of Presence, Involvement, Physiological Arousal, and Aggression. Journal of Communication, 57(3), 532-555.

Kusuma, W. (2017). Aksi “Klitih” Kembali Terjadi di Yogyakarta, Seorang Pelajar SMP Tewas Kompas.com. Diambil 7 Juni 2017, darihttp://regional.kompas.com/read/2017/03/13/17592971/ aksi.klitih.kembali.terjadi.di.yogyakarta.seorang.pelajar.smp.tewas

Li, Q. (2008). Cyberbullying in Schools: An Examination of Preservice Teachers' Perception. Canadian Journal of Learning and Technology/La revue canadienne de l'apprentissage et de la technologie, 34(2).

MacNeil, A. J., Prater, D. L., \& Busch, S. (2009). The Effects of School Culture and Climate on Student Achievement. International Journal of Leadership in Education, 12(1), 73-84.

Murray-Close, D., Ostrov, J. M., Nelson, D. A., Crick, N. R., \& Coccaro, E. F. (2010). Proactive, Reactive, and Romantic Relational Aggression in Adulthood: Measurement, Predictive Validity, Gender Differences, and Association with Intermittent Explosive Disorder. Journal of Psychiatric Research, 44(6), 393-404.

Nisfiannoor, M., \& Yulianti, E. (2005). Perbandingan Perilaku Agresif antara Remaja. Jurnal Psikologi, 3(1), 1-18.

Roberton, T., Daffern, M., \& Bucks, R. S. (2012). Emotion Regulation and Aggression. Aggression and Violent Behavior, 17(1), 72-82.

Saputra, W. N. E. (2016). Pendidikan Kedamaian: Peluang Penerapan pada Pendidikan Tingkat Dasar di Indonesia. Jurnal CARE (Children Advisory Research and Education), 3(3), 88-94.

Saputra, W. N. E., \& Handaka, I. B. (2017a). Analisis Validitas dan Reliabilitas Skala Perilaku Agresi. In Seminar Nasional Peran Bimbingan dan Konseling dalam Penguatan Pendidikan Karakter.

Saputra, W. N. E., \& Handaka, I. B. (2017b). Konseling Kedamaian: Strategi Konselor untuk Mereduksi Perilaku Agresi Remaja. In Seminar Nasional dengan Tema Pendidikan Karakter di Era Teknologi Informasi dalam Bingkai Multikultural.

Saputra, W. N. E., Widiasari, S. W., \& Dina, D. A. M. (2016). Peace Education: Islamic Perspective. In 1st International Conference on Islamic Education.

Scott, L. N., Stepp, S. D., \& Pilkonis, P. A. (2014). Prospective Associations between Features of Borderline Personality Disorder, Emotion Dysregulation, and Aggression. Personality Disorders: Theory, Research, and Treatment, 5(3), 278.

Valois, R. F., Zullig, K. J., \& Revels, A. A. (2017). Aggressive and Violent Behavior and Emotional Self-efficacy: Is There a Relationship for Adolescents? Journal of School Health, 87(4), 269277.

Winarlin, R., Lasan, B. B., \& Widada, W. (2016). Efektivitas Teknik Sosiodrama Melalui Bimbingan Kelompok untuk Mengurangi Perilaku Agresif Verbal Siswa SMP. Jurnal Kajian Bimbingan dan Konseling, 1(2), 68-73. http://dx.doi.org/10.17977/um001v1i22016p068 